\title{
PERANCANGAN APLIKASI PARIWISATA KUANTAN SINGINGI BERBASIS ANDROID MENGGUNAKAN PUSH NOTIFICATION DAN LBS
}

\author{
Ramadhan $^{1)}$, Feri Candra ${ }^{2)}$ \\ ${ }^{12}$ Teknik Informatika, Fakultas Teknik, Universitas Riau \\ 1ramadhan.ramadhan@stundent.unri.ac.id, 2feri@eng.unri.ac.id
}

\begin{abstract}
Kuantan Singingi is one of the regencies in Riau Province that is visited by many tourists every year, this is because there is an annual event held by the government, the 'Pacu Jalur' performance which is now included in the National Tourism Calendar. The number of tourists who come to Kuantan Singingi makes the need for tourism information in Kuansing increase, therefore the aim of this research is to develop an android-based tourism application using Push Notification and Location Based Services. The stages of designing this tourism application using the Waterfall method. This research resulted in an Android-based Kuantan Singingi Tourism Application that can be used to help tourists as evidenced by the percentage results of $87.2 \%$ with the category 'Very Satisfying' and helping the government promote Kuansing tourism as evidenced by the results of a percentage of $87.5 \%$ with the category 'Very Satisfying'.
\end{abstract}

Keywords: Location Based Service, Push Notification, Android, Waterfall, Kuantan Singingi

\begin{abstract}
Abstrak
Kuantan Singingi merupakan salah satu Kabupaten di Provinsi Riau yang dikunjungi banyak wisatawan setiap tahunnya, hal ini dikarenakan terdapat sebuah event tahunan yang digelar oleh pemerintah yaitu pagelaran 'Pacu Jalur' yang saat ini sudah masuk dalam Kalender Pariwisata Nasional. Banyaknya wisatawan yang datang ke Kuantan Singingi membuat kebutuhan akan informasi pariwisata di Kuansing meningkat, oleh karena itu tujuan dari penelitian ini adalah untuk mengembangkan aplikasi pariwisata berbasis android menggunakan Push Notification dan Layanan Berbasis Lokasi. Tahapan perancangan aplikasi pariwisata ini menggunakan metode Waterfall. Penelitian ini menghasilkan Aplikasi Wisata Kuantan Singingi yang berbasis Android yang dapat digunakan untuk membantu wisatawan yang dibuktikan dengan hasil persentase sebesar 87.2\% dengan kategori 'Sangat Memuaskan' dan membantu pemerintah mempromosikan pariwisata Kuansing yang dibuktikan dengan hasil persentase sebesar 87.5\% dengan kategori 'Sangat Memuaskan'.
\end{abstract}

Keywords: Location Based Service, Push Notification, Android, Waterfall, Kuantan Singingi

\section{PENDAHULUAN}

Kabupaten Kuantan Singingi merupakan salah satu Kabupaten di Provinsi Riau yang paling banyak dikunjungi oleh wisatawan. Hal ini dikarenakan di Kabupaten Kuantan Singingi terdapat salah satu event tahunan yang menarik minat wisatawan untuk berkunjung. Menurut salah satu badan statistika kota Kuantan Singingi jumlah wisatawan pada tahun 2017 mencapai 400.000 orang baik wisatawan lokal maupun mancanegara dan akan terus meningkat setiap tahunnya [1]. Banyaknya jumlah wisatawan yang datang ke Kabupaten Kuansing setiap tahunnya menjadi salah satu sebab diperlukannya media promosi yang tepat untuk memberikan informasiinformasi mengenai pariwisata baik event-event dan objek wisata yang ada di Kabupaten Kuantan Singingi. Sebelumnya informasi mengenai pariwisata di Kuantan Singingi disalurkan melalui beberapa media promosi seperti pamphlet, media sosial (facebook dan instagram), website dan beberapa sarana promosi 
lain. Namun media promosi pariwisata yang telah disebutkan sebelumnya masih belum memberikan informasi yang maksimal kepada wisatawan.

Perkembangan teknologi perangkat mobile berbasis android menawarkan berbagai macam keuntungan yang dapat dimanfaatkan untuk mempromosikan pariwisata, salah satu kelebihan teknologi mobile saat ini adalah teknologi Mobile GIS (Geografihic Information System) yang telah terpasangnya teknologi Location Based Service (LBS), dengan adanya layanan tersebut akan semakin mempermudah untuk menunjukkan akses menuju lokasi objek wisata [2]. Selain itu kelebihan yang terdapat pada android adalah adanya teknologi Push Notification, Push Notification merupakan mekanisme berbasis event untuk mengirim informasi ke perangkat mobile klien [3]. Dengan menggunakan teknologi tersebut administrator memberikan informasi kepada pengguna tanpa sepengetahuan atau usaha pengguna maka dari itu teknologi ini dapat memberikan keuntungan dalam mempromosikan pariwisata dikarenakan dapat membantu wisatawan mendapatkan informasi dengan mudah [4]. Selain itu penggunan perangkat mobile berbasis android juga dianggap tepat untuk mempromosikan pariwisata dikarenakan dapat memudahkan wisatawan untuk mengakses informasi, dengan menggunakan aplikasi berbasis android pengguna dapat mengakses informasi meskipun dalam keadaan koneksi internet yang tidak stabil [5].

Berdasarkan uraian sebelumnya maka aplikasi berbasis android mempunyai banyak keunggulan yang dapat digunakan sebagai media promosi pariwisata yang memudahkan wisatawan untuk dapat memperoleh informasi pariwisata yang tentunya mudah untuk digunakan. Aplikasi panduan pariwisata Kuantan Singingi ini didesain dengan fitur-fitur yang lengkap seperti adanya informasi mengenai objek wisata dan event tahunan yang diadakan oleh pemerintah kabupaten Kuansing setiap tahunnya dan juga aplikasi ini dapat memberikan informasi yang didukung dengan data visual seperti foto mengenai objek wisata dan event tersebut. Selain informasi mengenai objek wisata aplikasi ini juga dilengkapi dengan informasi mengenai lokasi menuju objek wisata (dalam bentuk maps), akses menuju objek wisata, fasilitas-fasilitas yang ada di objek wisata yang ingin dituju serta estimasi biaya yang dikeluarkan untuk menikmati objek wisata terkait.

\section{METODE PENELITIAN}

Metode pengembangan sistem dalam penelitian ini menggunakan metode waterfall. Metode ini menyediakan pendekatan alur hidup perangkat lunak secara berurutan dan sistematis dimulai dari kegiatan analisis, desain, pengodean, pengujian dan tahap pendukung (support) [6]. Alur dan sistematika metode waterfall dapat dilihat pada Gambar 1.

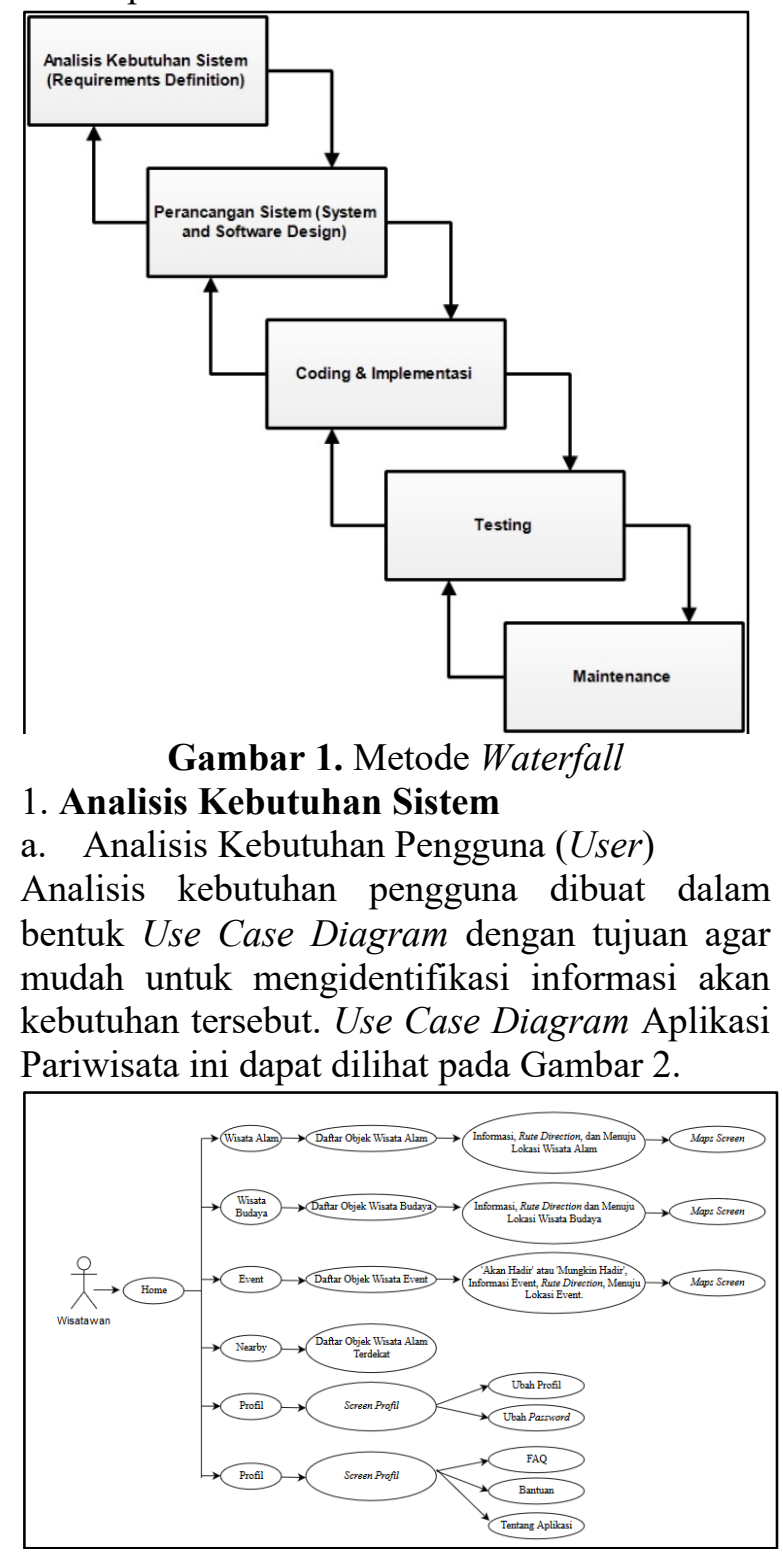

Gambar 2. Use Case Diagram 
b. Analisis Kebutuhan Software

Untuk membuat aplikasi ini, beberapa software yang digunakan adalah sebagai berikut:

a) Software Android Studio

b) LBS, Maps API dan GPS

c) Software Corel Draw digunakan untuk mengedit foto pariwisata

d) Notepad++ digunakan untuk editing coding

e) Software Android SDK yang digunakan sebagai alat bantu dan API dalam mengembangkan aplikasi.

c. Analisis Kebutuhan Hardware

Untuk membuat aplikasi ini, beberapa hardware yang digunakan adalah sebagai berikut:

a) PC/Laptop dengan spesifikasi minimal processor Intel(R) Core (TM) i5-4210U CPU

(a) $1.70 \mathrm{GH}_{\mathrm{z}} 2,40 \mathrm{GH}_{\mathrm{z}}$ dengan Memory 4 GB RAM digunakan untuk pembuatan aplikasi.

b) Smartphone Android versi 5.0 digunakan untuk melakukan uji coba aplikasi.

c) Random Access Memory digunakan untuk menyimpan data.

d) Modem/Wifi digunakan untuk mengakses internet.

Adapun untuk pengguna minimum requirement smartphone untuk menjalankan aplikasi Pariwisata Kuantan Singingi ini adalah sebagai berikut:
a) Processor $1 \mathrm{GHz}$
b) RAM $1 \mathrm{~GB}$
c) Internal Storage $8 \mathrm{~GB}$
d) OS Android versi 5.0 (Lolipop)
e) Internet

\section{Perancangan Sistem (Design)}

\section{a. Flowchart}

Pada perancangan aplikasi pariwisata Kuantan Singingi terdapat dua flowchart yang terdiri dari flowchart user dan flowchart admin. flowchart user dan flowchart admin dapat dilihat pada Gambar 3 dan 4.

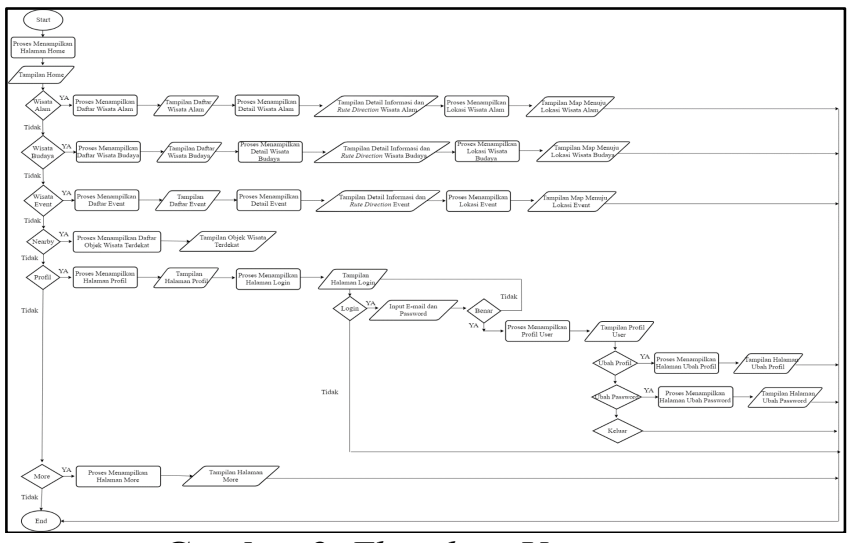

Gambar 3. Flowchart User

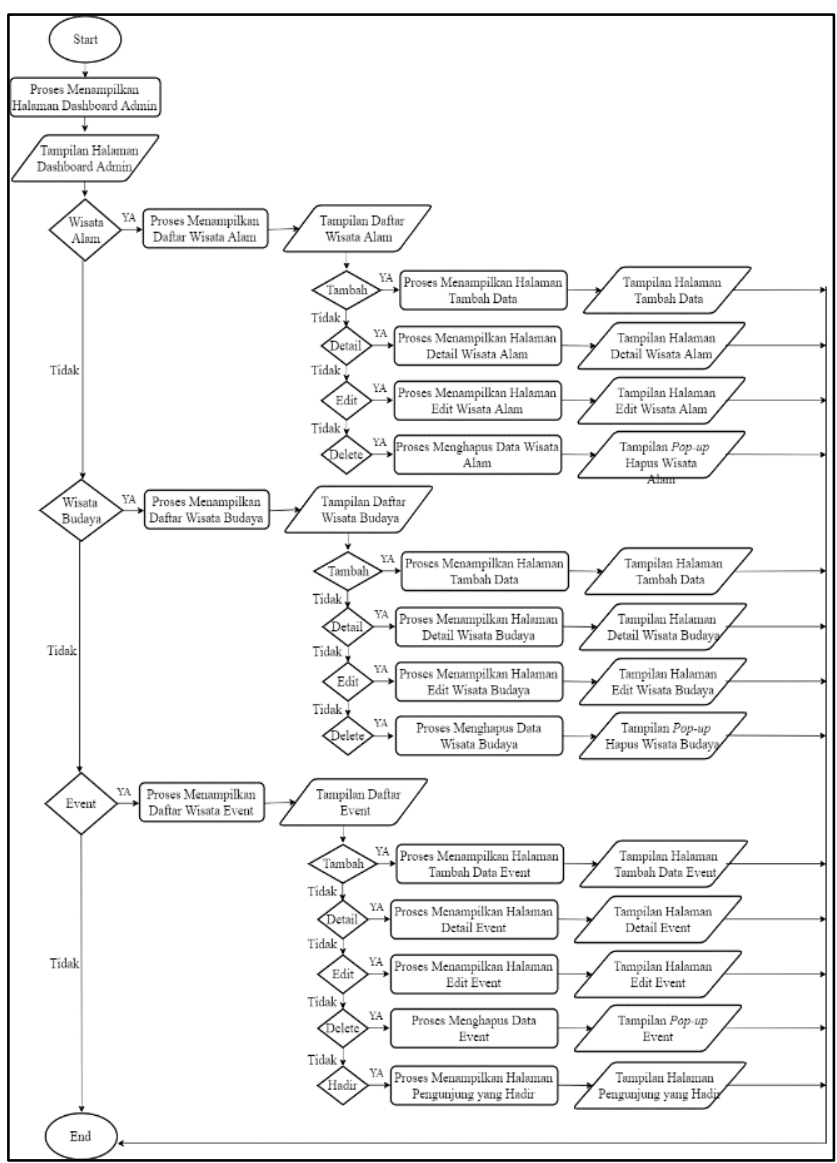

Gambar 4. Flowchart Admin

b. Activity Diagram

Activity diagram merupakan diagram yang berfungsi untuk menggambarkan jalan kerja suatu sistem. Activity diagram dapat dilihat pada Gambar 5. 


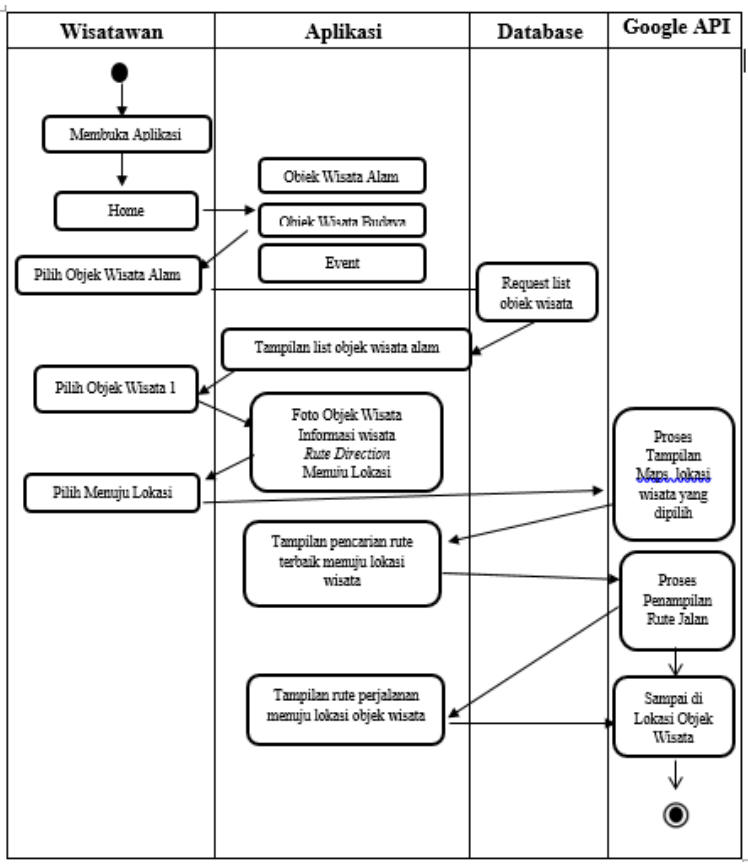

Gambar 5. Activity Diagram

c. Sequence Diagram

Sequence diagram atau diagram urutan merupakan diagram yang menampilkan interaksi-interaksi antar objek pada sistem yang disusun dengan urutan waktu. Berikut merupakan sequence diagram informasi wisata dan lokasi wisata yang dapat dilihat pada Gambar 6 dan 7.

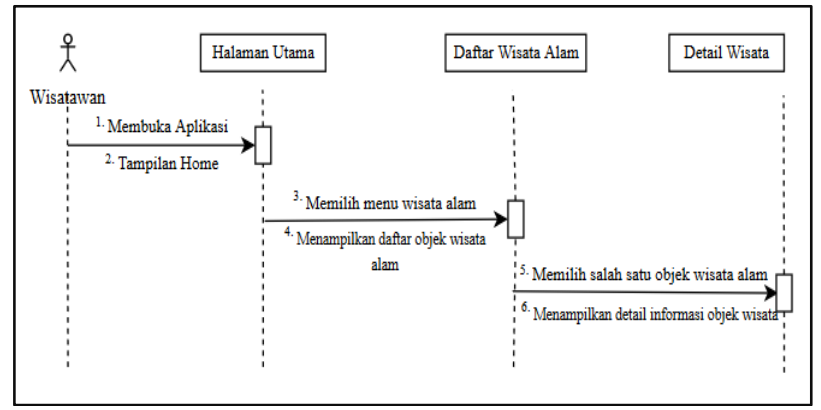

Gambar 6. Sequence Diagram Informasi Wisata

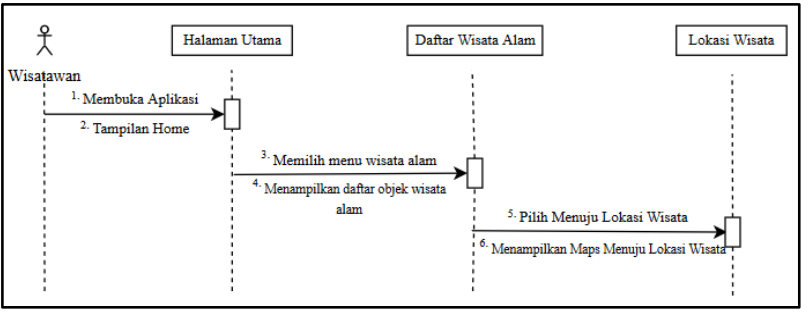

Gambar 7. Sequence Diagram Lokasi Wisata
Pada tahap ini juga dilakukan pengujian tentang kemudahan yang dirasakan pengguna terhadap sistem yang dirancang dengan cara melakukan pengujian Black Box Testing yaitu pengujian yang bertujuan untuk mengetahui apakah semua fungsi perangkat lunak telah berjalan sebagaimana mestinya sesuai dengan kebutuhan fungsional yang telah didefinisikan dan diharapkan sebelumnya [7] dan Usability Testing dengan memberikan pernyataan-pernyataan dalam bentuk kuesioner [8].

Untuk mengetahui tingkat peresentase dari kemudahan yang diberikan sistem informasi penggajian digunakanlah cara perhitungan menggunakan rumus berikut [9].

$$
\begin{aligned}
& \text { Persentase Kemudahan (\%) } \\
& =\frac{\text { skor yang diobservasi }}{\text { skor yang diharapkan }} \times 100 \%
\end{aligned}
$$

\section{HASIL DAN PEMBAHASAN}

\section{Interface Website}

Interface website merupakan tampilan yang dapat digunakan admin dari aplikasi pariwisata di Kuantan Singingi untuk menambahkan, mengedit dan menghapus data pada aplikasi pariwisata yang dapat dilakukan oleh admin pada website yang telah disediakan secara Real Time. Berikut adalah tampilan admin interface website pada Aplikasi Pariwisata Kuantan Singingi.

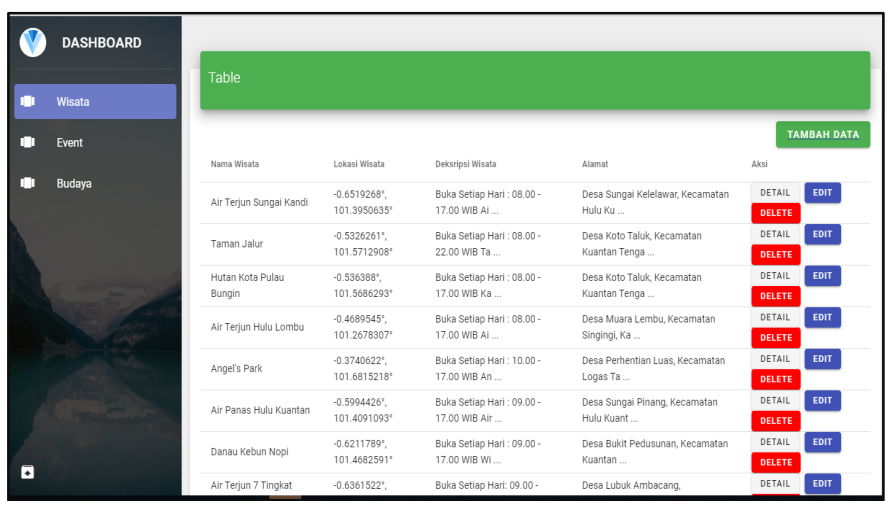

Gambar 8. Interface Daftar Wisata Website 

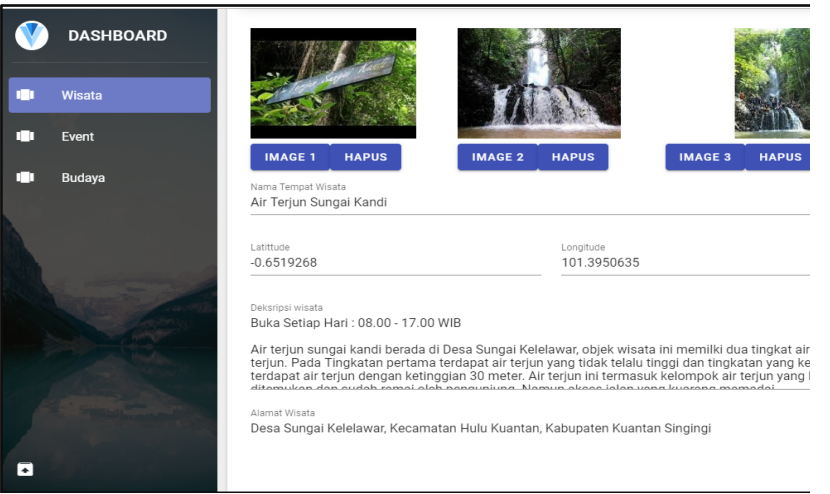

Nama Tempat Westo
Air Terjun Sungai Kandi

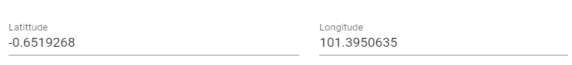

Deksripsi wisata
Buka Setiap Hari : 08.00-17.00 WIB

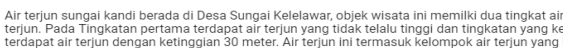

Alamot Wisera

Alamst Wisera
Desa Sungai Kelelawar, Kecamatan Hulu Kuantan, Kabupaten Kuantan Singingi

Gambar 9. Interface Edit Informasi Wisata

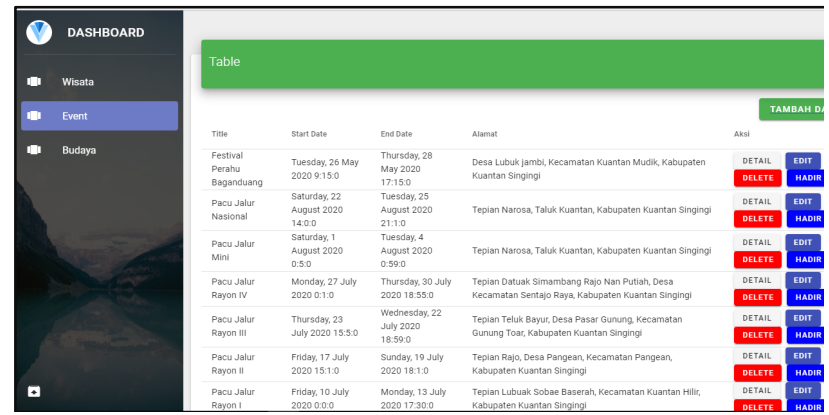

Gambar 10. Interface Daftar Event

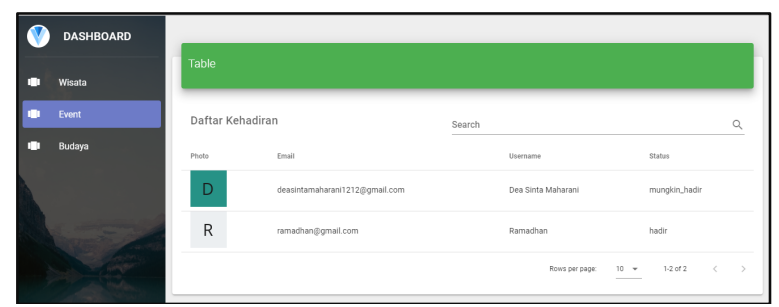

Gambar 11. Interface Daftar Kehadiran

\section{User Interface Versi Android}

User Interface (UI) merupakan halaman antarmuka pengguna aplikasi Pariwisata Kuantan Singingi berbasis Android. Berikut adalah tampilan Aplikasi pariwisata Kuantan Singingi.

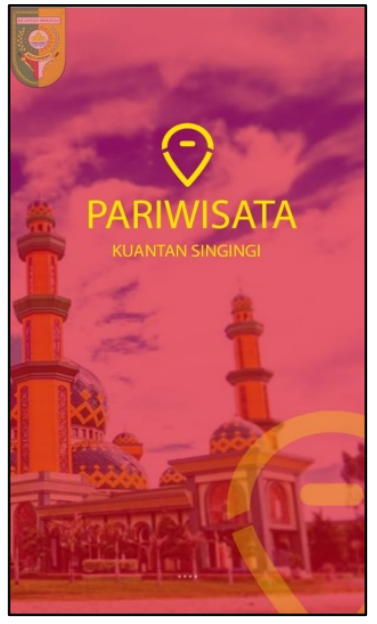

Gambar 12. Splash Screen
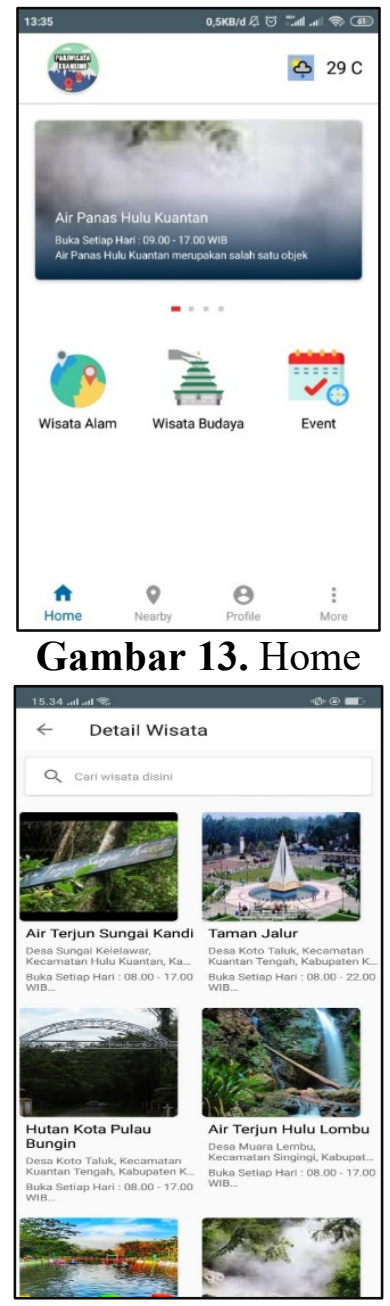

Gambar 14. Daftar Wisata Alam 


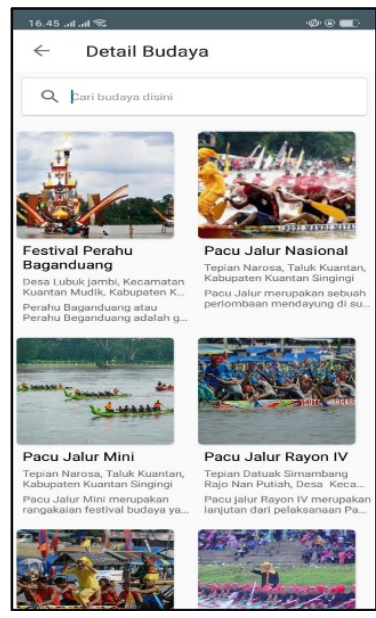

Gambar 15. Daftar Wisata Budaya

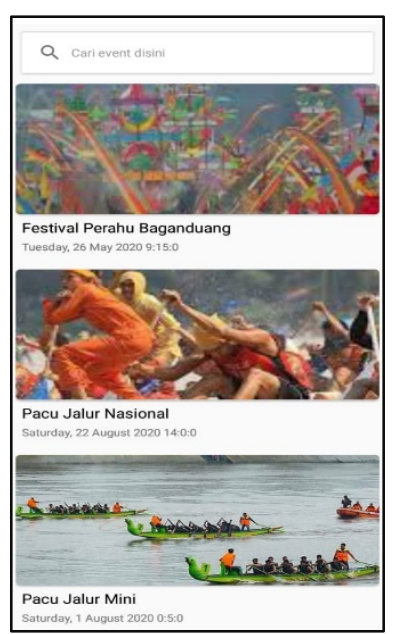

Gambar 16. Daftar Event

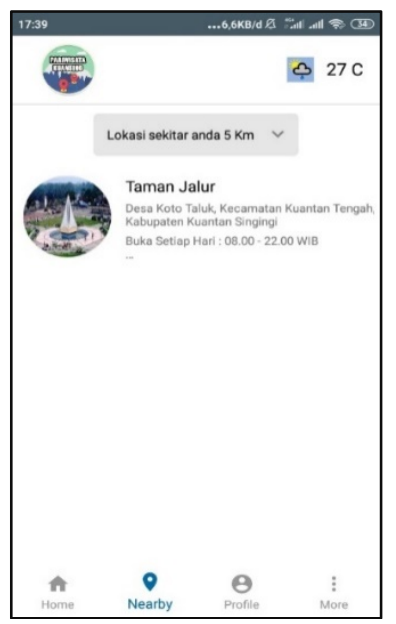

Gambar 4.17. Nearby

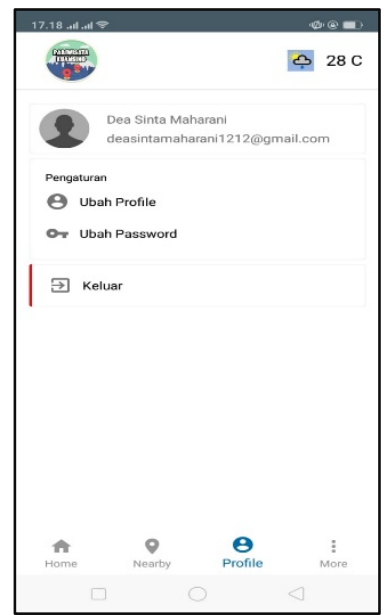

Gambar 4.18. Profil

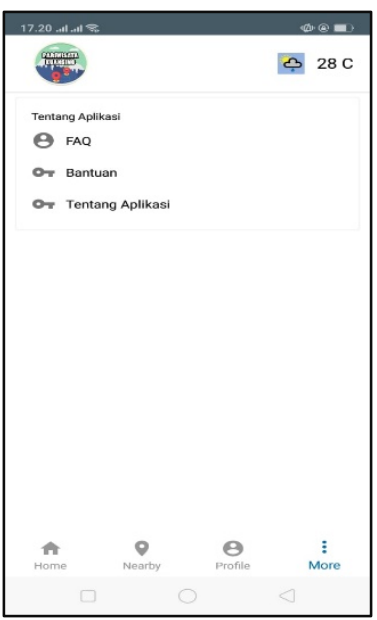

Gambar 4.19 More

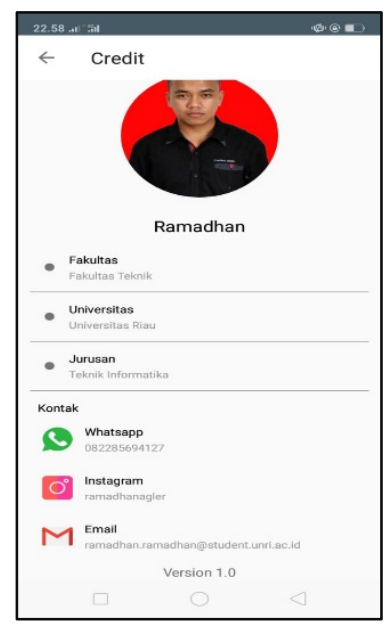

Gambar 4.20. Credit 


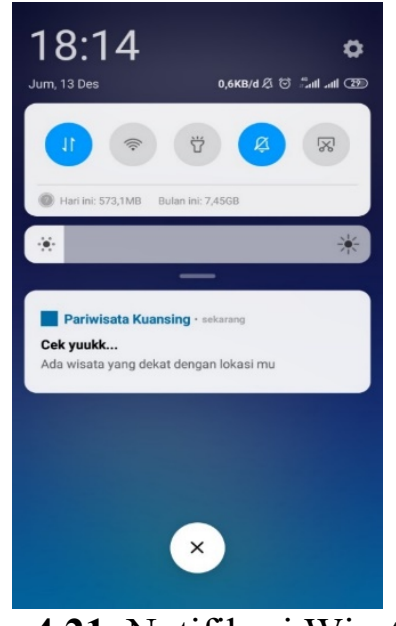

Gambar 4.21. Notifikasi Wisata Alam
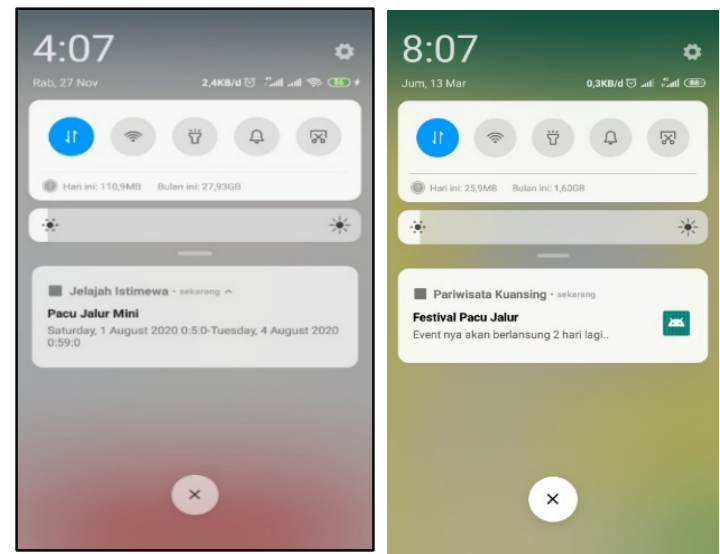

Gambar 4.22. Notifikasi Event

\section{Hasil Pengujian Black Box}

a. Pengujian Versi Android

Tabel 1. Pengujian Versi Android

\begin{tabular}{|c|c|c|c|}
\hline NO & $\begin{array}{c}\text { Skenario } \\
\text { Pengujian }\end{array}$ & $\begin{array}{l}\text { Hasil Yang } \\
\text { Diharapkan }\end{array}$ & $\begin{array}{c}\text { Hasil } \\
\text { Uji }\end{array}$ \\
\hline 1. & $\begin{array}{l}\text { Pengujian pada } \\
\text { android versi } 5.0 \\
\text { (Lollipop) }\end{array}$ & $\begin{array}{c}\text { Kompatibel } \\
\text { dengan Android } \\
\text { versi } 5.0 \\
\text { (Lollipop) }\end{array}$ & Berhasil \\
\hline 2. & $\begin{array}{l}\text { Pengujian pada } \\
\text { android versi } 6.0 \\
\text { (Marshmallow) }\end{array}$ & $\begin{array}{c}\text { Kompatibel } \\
\text { dengan Android } \\
\text { versi } 6.0 \\
\text { (Marshmallow) }\end{array}$ & Berhasil \\
\hline 3. & $\begin{array}{c}\text { Pengujian pada } \\
\text { android versi } 7.0 \\
\text { (Nougat) }\end{array}$ & $\begin{array}{c}\text { Kompatibel } \\
\text { dengan Android } \\
\text { versi } 7.0 \\
\text { (Nougat) } \\
\end{array}$ & Berhasil \\
\hline 4. & $\begin{array}{l}\text { Pengujian pada } \\
\text { android versi } 8.0 \\
\text { (Oreo) }\end{array}$ & $\begin{array}{c}\text { Kompatibel } \\
\text { dengan Android } \\
\text { versi } 8.0 \text { (Oreo) }\end{array}$ & Berhasil \\
\hline 5. & $\begin{array}{l}\text { Pengujian pada } \\
\text { android versi } 9.0 \\
\text { (Pie) }\end{array}$ & $\begin{array}{c}\text { Kompatibel } \\
\text { dengan Android } \\
\text { versi } 9.0(\mathrm{Pie})\end{array}$ & Berhasil \\
\hline
\end{tabular}

b. Pengujian Ukuran Layar

Tabel 2. Pengujian Ukuran Layar

\begin{tabular}{|c|c|c|c|}
\hline NO & $\begin{array}{l}\text { Skenario } \\
\text { Pengujian }\end{array}$ & $\begin{array}{l}\text { Hasil Yang } \\
\text { Diharapkan }\end{array}$ & $\begin{array}{c}\text { Hasil } \\
\text { Uji }\end{array}$ \\
\hline 1. & $\begin{array}{c}\text { Pengujian } \\
\text { pada Android } \\
\text { dengan } \\
\text { ukuran layar } 5 \\
\text { inch }\end{array}$ & $\begin{array}{l}\text { Tampilan terlihat } \\
\text { sesuai atau baik } \\
\text { pada Android } \\
\text { dengan ukuran } \\
\text { layar } 5 \text { inch }\end{array}$ & Berhasil \\
\hline 2. & $\begin{array}{c}\text { Pengujian } \\
\text { pada Android } \\
\text { dengan } \\
\text { ukuran layar } \\
\text { 5,5 inch }\end{array}$ & $\begin{array}{l}\text { Tampilan terlihat } \\
\text { sesuai atau baik } \\
\text { pada Android } \\
\text { dengan ukuran } \\
\text { layar 5,5 inch }\end{array}$ & Berhasil \\
\hline 3. & $\begin{array}{l}\text { Pengujian } \\
\text { pada Android } \\
\text { dengan } \\
\text { ukuran layar } \\
6.2 \text { inch } \\
\end{array}$ & $\begin{array}{l}\text { Tampilan terlihat } \\
\text { sesuai atau baik } \\
\text { pada Android } \\
\text { dengan ukuran } \\
\text { layar } 6.2 \text { inch }\end{array}$ & Berhasil \\
\hline 4. & $\begin{array}{c}\text { Pengujian } \\
\text { pada Android } \\
\text { dengan } \\
\text { ukuran layar } \\
6.3 \text { inch }\end{array}$ & $\begin{array}{l}\text { Tampilan terlihat } \\
\text { sesuai atau baik } \\
\text { pada Android } \\
\text { dengan ukuran } \\
\text { layar } 6.3 \text { inch }\end{array}$ & Berhasil \\
\hline
\end{tabular}

c. Pengujian User Interface (UI)

Tabel 3. Pengujian User Interface (UI)

\begin{tabular}{|c|c|c|c|}
\hline NO & Pengujian & $\begin{array}{l}\text { Hasil Yang } \\
\text { Diharapkan }\end{array}$ & $\begin{array}{c}\text { Hasil } \\
\text { Uji }\end{array}$ \\
\hline 1. & $\begin{array}{l}\text { Icon } \\
\text { Pariwisata } \\
\text { Kuantan } \\
\text { Singingi }\end{array}$ & $\begin{array}{l}\text { Membuka aplikasi } \\
\text { dan menampilkan } \\
\text { SplashScreen }\end{array}$ & Berhasil \\
\hline 2. & Button Home & $\begin{array}{l}\text { Menampilkan } \\
\text { layout beranda } \\
\text { aplikasi }\end{array}$ & Berhasil \\
\hline 3. & $\begin{array}{l}\text { Button } \\
\text { Nearby }\end{array}$ & $\begin{array}{l}\text { Menampilkan } \\
\text { layout daftar wisata } \\
\text { disekitar user }\end{array}$ & Berhasil \\
\hline 4. & Button Profil & $\begin{array}{c}\text { Menampilkan } \\
\text { layout login dan } \\
\text { informasi akun user }\end{array}$ & Berhasil \\
\hline 5. & Button More & $\begin{array}{c}\text { Menampilkan } \\
\text { costum dialog } \\
\text { informasi aplikasi }\end{array}$ & Berhasil \\
\hline 6. & $\begin{array}{l}\text { Fungsi Menu } \\
\text { Wisata Alam }\end{array}$ & $\begin{array}{l}\text { Menampilkan } \\
\text { layout pilihan objek } \\
\text { wisata alam } \\
\text { kuantan singingi }\end{array}$ & Berhasil \\
\hline 7. & $\begin{array}{l}\text { Fungsi Menu } \\
\text { Menuju } \\
\text { Lokasi Wisata } \\
\text { Alam }\end{array}$ & $\begin{array}{c}\text { Menampilkan } \\
\text { layout Maps dan } \\
\text { petunjuk jalan } \\
\text { menuju lokasi } \\
\text { objek wisata alam }\end{array}$ & Berhasil \\
\hline
\end{tabular}




\begin{tabular}{|c|c|c|c|}
\hline 8. & $\begin{array}{c}\text { Fungsi Menu } \\
\text { Wisata } \\
\text { Budaya }\end{array}$ & $\begin{array}{l}\text { Menampilkan } \\
\text { layout pilihan objek } \\
\text { wisata budaya } \\
\text { kuantan singingi }\end{array}$ & Berhasil \\
\hline 9. & $\begin{array}{l}\text { Fungsi Menu } \\
\text { Menuju } \\
\text { Lokasi Wisata } \\
\text { Budaya }\end{array}$ & $\begin{array}{c}\text { Menampilkan } \\
\text { layout Maps dan } \\
\text { petunjuk jalan } \\
\text { menuju lokasi } \\
\text { objek wisata } \\
\text { budaya }\end{array}$ & Berhasil \\
\hline 10. & $\begin{array}{c}\text { Fungsi Menu } \\
\text { Event }\end{array}$ & $\begin{array}{c}\text { Menampilkan } \\
\text { layout pilihan event } \\
\text { di kuantan singingi }\end{array}$ & Berhasil \\
\hline 11. & $\begin{array}{l}\text { Button 'Akan } \\
\text { Hadir' atau } \\
\text { 'Mungkin } \\
\text { Akan Hadir' }\end{array}$ & $\begin{array}{c}\text { Warna button } \\
\text { 'Akan Hadir' atau } \\
\text { 'Mungkin Akan } \\
\text { Hadir' akan } \\
\text { berubah sesuai } \\
\text { dengan button yang } \\
\text { dipilih pengguna }\end{array}$ & Berhasil \\
\hline 12. & $\begin{array}{l}\text { Fungsi Menu } \\
\text { Menuju } \\
\text { Lokasi Event }\end{array}$ & $\begin{array}{c}\text { Menampilkan } \\
\text { layout Maps dan } \\
\text { petunjuk jalan } \\
\text { menuju lokasi } \\
\text { penyelenggaraan } \\
\text { event }\end{array}$ & Berhasil \\
\hline
\end{tabular}

\section{d. Pengujian Koneksi Internet dan GPS}

Tabel 4. Pengujian Koneksi Internet dan GPS

\begin{tabular}{|c|c|c|c|}
\hline NO & $\begin{array}{l}\text { Skenario } \\
\text { Pengujian }\end{array}$ & $\begin{array}{l}\text { Hasil Yang } \\
\text { Diharapkan }\end{array}$ & $\begin{array}{c}\text { Hasil } \\
\text { Uji }\end{array}$ \\
\hline 1. & $\begin{array}{c}\text { Koneksi } \\
\text { internet stabil } \\
\text { dan GPS aktif }\end{array}$ & $\begin{array}{c}\text { Aplikasi berjalan } \\
\text { dengan lancar saat } \\
\text { melakukan } \\
\text { pencarian lokasi } \\
\text { wisata }\end{array}$ & Berhasil \\
\hline 2. & $\begin{array}{c}\text { Koneksi } \\
\text { internet tidak } \\
\text { stabil dan } \\
\text { GPS aktif }\end{array}$ & $\begin{array}{c}\text { Aplikasi berjalan } \\
\text { dengan lancar saat } \\
\text { melakukan } \\
\text { pencarian lokasi } \\
\text { wisata }\end{array}$ & Berhasil \\
\hline 3. & $\begin{array}{c}\text { Koneksi } \\
\text { internet stabil } \\
\text { dan GPS tidak } \\
\text { aktif }\end{array}$ & $\begin{array}{c}\text { Aplikasi berjalan } \\
\text { dengan lancar saat } \\
\text { melakukan } \\
\text { pencarian lokasi } \\
\text { wisata }\end{array}$ & $\begin{array}{c}\text { Tidak } \\
\text { Berhasil }\end{array}$ \\
\hline 4. & $\begin{array}{c}\text { Koneksi } \\
\text { internet tidak } \\
\text { stabil dan } \\
\text { GPS tidak } \\
\text { aktif }\end{array}$ & $\begin{array}{c}\text { Aplikasi berjalan } \\
\text { dengan lancar saat } \\
\text { melakukan } \\
\text { pencarian lokasi } \\
\text { wisata }\end{array}$ & $\begin{array}{c}\text { Tidak } \\
\text { Berhasil }\end{array}$ \\
\hline
\end{tabular}

\section{Hasil Pengujian Usability Testing}

Pengujian Usability Testing pada aplikasi Pariwisata Kuantan Singingi diberikan kepada lima orang staff bidang promomsi pariwisata Dinas Pariwisata Kuantan Singingi sebagai administrator yang akan memasukkan informasi seputar pariwisata Kuansing.

$$
\begin{aligned}
\text { Persentase Kemudahan } & =\frac{\text { Skor yang Diobservasi }}{\text { Skor yang Diharapkan }} \times 100 \% \\
& =\frac{175}{200} \times 100 \% \\
& =87,5 \%
\end{aligned}
$$

Berdasarkan hasil perhitungan persentase kemudahan di atas diketahui bahwa kemudahan penggunaan aplikasi Pariwisata Kuantan Singingi mendapat total skor 175 dengan persentase 87.5\% dengan kategori Sangat Memudahkan.

Serta quesioner yang diberikan kepada 15 orang pengguna yang diberikan secara acak kepada orang yang berkunjung ke Kuantan Singingi.

$$
\begin{aligned}
\text { Persentase Kemudahan } & =\frac{\text { Skor yang Diobservasi }}{\text { Skor yang Diharapkan }} \times 100 \% \\
& =\frac{523}{600} \times 100 \% \\
& =87,2 \%
\end{aligned}
$$

Berdasarkan hasil perhitungan persentase kemudahan di atas diketahui bahwa kemudahan penggunaan aplikasi Pariwisata Kuantan Singingi oleh lima belas orang responden pengguna Aplikasi Pariwisara Kuantan Singingi mendapat total skor 523 dengan persentase $87.2 \%$ dengan kategori Sangat Memudahkan.

\section{KESIMPULAN}

Berdasarkan hasil perancangan aplikasi Pariwisata Kuansing, maka dapat diperoleh beberapa simpulan yaitu:

1. Aplikasi ini membantu pemerintah Kuantan Singingi mempromosikan pariwisata Kuansing 
yang dibuktikan dengan persentase sebesar $87.5 \%$ dengan kategori Sangat Memudahkan.

2. Aplikasi ini membantu wisatawan yang untuk mendapatkan informasi seputar pariwisata Kuansing yang dibuktikan dengan persentase sebesar 87.2\% dengan kategori Sangat Memudahkan.

3. Aplikasi dapat berjalan dengan baik pada versi android serta ukuran layar yang telah ditetapkan, seluruh button dan fungsi menu pada aplikasi berjalan dengan baik dan sesuai dengan yang telah ditetapkan serta aplikasi dapat berjalan dengan baik pada koneksi internet dan GPS yang stabil.

\section{DAFTAR PUSTAKA}

[1] Badan Pusat Statistik Kuansing. 2017. Demografi.

https://kuansing.go.id/id/page/demografi.h tml (diakses pada 12 Desember 2019 Pukul 14.36 WIB). PP 3.

[2] Sasmito, W., S. 2017. Penerapan Metode Waterfall Pada Desain Sistem Informasi Geografis Industri Kabupaten Tegal. Jurnal Pengembangan IT (JPIT) Vol. 2 No. 1. Penerbit: JPIT. Tegal. PP 22-28.

[3] Wadate, C, dkk. 2014. A Survey of Automatic WiFi based Push Notification in College Campus using Cloud. International Journal of Computer Applications. Vol 8, No 1. Penerbit: University of Karlsruhe. Jerman. PP 28-35.
[4] Darmawan, R. 2019. Implementasi Push Notification Scheduler pada Firebase Cloud Messaging untuk Aplikasi Peringatan Kegiatan Organisasi Menggunakan Flutter Berbasis Mobile. Skripsi. STMIK AKAKOM. Yogyakarta. PP 10-11.

[5] Safaat H, N. 2012. Pemrograman Aplikasi Mobile Smarthphone dan Tablet PC Berbasis Android. Penerbit: Informatika. Bandung. PP 35-37.

[6] Pressman, R. S. 2015. Rekayasa Perangkat Lunak: Pendekatan Praktisi Buku I. Penerbit: ANDI. Yogyakarta. PP 33.

[7] Setiawan, G. S. 2011. Pengujian Perangkat Lunak Menggunakan Metode Black Box Studi Kasus Exelsa Universitas Sanata Dharma. Skripsi. Penerbit: Fakultas Sains Dan Teknologi, Universitas Sanata Dharma. Yogyakarta. PP 18-20.

[8] Yumarlin, Mz. 2016. Evaluasi Penggunaan Website Universitas Janabadra dengan Menggunakan Metode Usability Testing. Jurnal Informasi Interaktif, Vol. 1, No. 1. Penerbit: Universitas Janabadra, Yogyakarta. PP 21-18.

[9] Hadiwijaya, I. 2014. Pengembangan Media Interaktif Waspada Demam Berdarah Dengue (DBD) Menggunkan Macromedia Flash 8. Skripsi. Jurusan Pendidikan Teknik Informatika, Fakultas Teknik, UNY. Yogyakarta. PP 18, 20.

[10] Abdullah, R. 2015. Web Programing is Easy. Penerbit: Elek Media Komputindo. Jakarta. PP 48-49. 